\title{
Ep. 5,66
}

Proc. Estonian Acad. Sci. Chem., 1989, 38, N 4, 225--229

удК 547.001

I. $U G I$

\section{FROM PENTAZOLE TO HIGH-DIMENSIONAL CHEMISTRY}

\author{
(Presented by K. Lääts)
}

After having finished his doctcral thesis "Steric hindrance of resonance in medium-sized rings" at the University of Munich, the present author discussed the choice of future research topics with his former doctoral adviser Prof. R. Huisgen, and he decided to begin his own scientific career in 1955 with an investigation of the classical problem whether or not pentazole derivatives are capable of existing. By 1958 phenyl pentazole 3 and some of its derivatives had been prepared, and the mechanism of their formation from 1 and $\mathrm{N}_{3}^{\ominus}$ had been eluridated ['].
$\mathrm{Ph}-\stackrel{\oplus}{\mathrm{N}} \equiv \mathrm{X}$
F 1
$1: X=N$
$P h-N_{N}^{Y}=\frac{N}{1}$
$3: Y=N$
$2 a: x=c^{\ominus}$
$4: Y=\mathrm{CH}$

In order to compare the UV-spectra of 3 and 4 , the latter was synthesized from $2 \mathrm{a}$, and it was noticed that then no generally applicable and efficient method was available $\left[{ }^{2}\right]$ for the preparation of isocyanides 2 .

Three independent research groups $\left[^{3-5}\right]$ found that isocyanides can be prepared conveniently from $\mathrm{N}$-monosubstituted formamides 5 by dehydration with phosgene $\left.{ }^{[6}\right]$, diphosgene $[7]$, phosphoryl chloride; $[5,8]$ or arene sulfonyl chlorides $[3,4]$ in the presence of bases.

$$
\underset{5}{\mathrm{R}-\mathrm{NH}-\mathrm{CHO}} \longrightarrow \frac{\mathrm{R}-\mathrm{N}^{\oplus} \equiv \mathrm{C}^{\ominus}}{2}
$$

In $1959 \mathrm{I}$. Ugi and his co-workers discovered the four-component condensation (4CC) $\left[{ }^{9}\right]$, since $1963\left[^{10}\right]$ generally quoted as the Ugi reaction. Amines 6 , carbonyl compounds 7 , isocyanides 2 and suitable acids 8 , or their anions, react to form $\alpha$-adducts 9 that undergo spontaneous secondary reactions to yield $\alpha$-amino acid derivatives whose chemical nature depends mainly on the nature of the acid component 8 .

F3

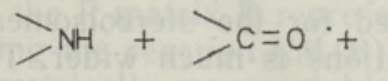

6

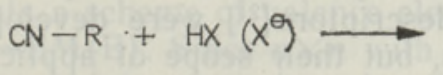

2<smiles>[R]N=C([X])CN(C)C</smiles>

9

The syntheses of peptides and $\beta$-lactam antibiotics $\left[{ }^{11},{ }^{12}\right]$, the most important applications of the 4CC, belong to the major research interest of the author since 1960. A new chiral amino acid unit is generated from an aldehyde and is incorporated into a peptide segment during peptide syntheses by stereoselective 4CC. Accordingly, this method is particularly useful for the synthesis of peptides containing unnatural amino acids. 
Chiral $\alpha$-ferrocenyl alkyl amines 11 a (see 16 ) [ $\left.{ }^{13}\right]$, and 1 -amino aldose derivatives $11 \mathrm{~b}\left[{ }^{12}\right]$ are the most promising chiral amino components 11 of such asymmetric syntheses, because

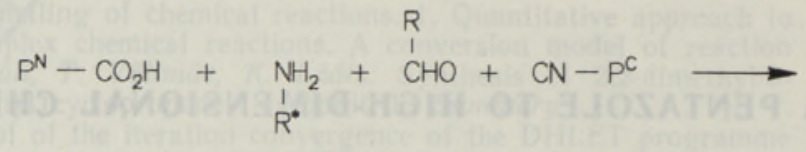

F4

$\begin{array}{llll}10 & 11 & 12 & 13\end{array}$

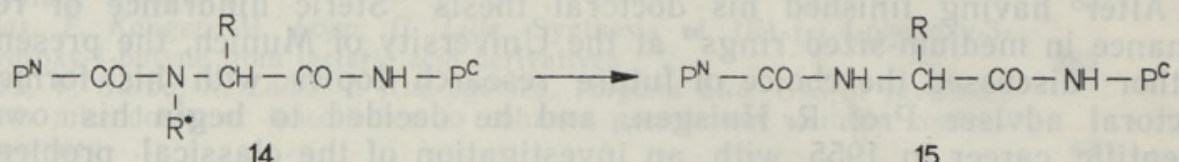

under suitable conditions, the $4 \mathrm{CCs}$ with $11 \mathrm{a}$ and $11 \mathrm{~b}$ proceed with a high degree of stereoselectivity and yield products 14 whose chiral auxiliary group $\mathrm{R}^{*}$ can be replaced by $\mathrm{H}$ under mild acidolytic conditions.

The stereoselective $4 \mathrm{CCs}$ are the origin of all other scientific interests and projects of this author and his co-workers $\left[{ }^{14}\right]$.

The extensive studies in ferrocene chemistry were carried out, because $\alpha$-ferrocenyl alkyl amines belong to the overall most suitable chiral templates for asymmetric 4CC. In this context, the synthesis of $\alpha$-ferrocenyl alkyl compounds 16 from aldehydes and ferrocene $\left[{ }^{15}\right]$ was elaborated, as well as the retentive $\mathrm{S}_{\mathrm{N}} \mathrm{l}$ reactions of $16\left[{ }^{16}\right]$ and

F5

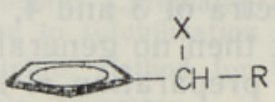

$\mathrm{Fe}$

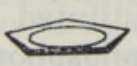

16

( $\mathrm{X}=\mathrm{OH}, \mathrm{OAC}, \mathrm{N}_{3}, \stackrel{\oplus}{\mathrm{N}} \mathrm{Me}_{3}, \mathrm{SCH}_{2} \mathrm{CO}_{2} \mathrm{H}$ )

the chelate-assisted highly stereoselective 2-metallation of $\alpha$-ferrocenyl N,N-dimethyl-ethylamine $\left[{ }^{17}\right]$, long before the chelate-assisted stereoselective metallations became fashionable [ $\left.{ }^{18}\right]$.

Since protective groups were needed that survive the acidolytic conditions of $14 \rightarrow 15$, the «orthogonal», Co(I)-cleavable protective groups were developed that are also useful in oligonucleotide chemistry [19, $\left.{ }^{20}\right]$.

The stereochemistry of ferrocene derivatives required a new classification and nomenclature system. The concept of permutational isomerism and permutational descriptors $\left[{ }^{21}\right]$ were developed for the stereoisomeric ferrocene derivatives, but their scope of applications is much wider. The first spin-off that permutational isomerism generated was a permutationbased treatment of the stereoisomerizations of the phosphorane derivatives, that led to the notion of «turnstile rotation» (TR) $\left[{ }^{22}\right]$ and the TR/BPR controversy that seems now to be resolved $\left[{ }^{23}\right]$.

Also some further theoretical/experimental studies in $\mathrm{P}(\mathrm{V})$ chemistry belonged to the sequel that ends in new phosphorylating reagents, e. g. 17 , and fast $\mathrm{P}(\mathrm{V})$ methods for oligonucleotide syntheses [ ${ }^{20,24}$.

Permutational isomerism is the conceptual foundation of the theory of chemical identity groups, an abstract, essentially non-geometric, unified approach to the stereochemistry of rigid and non-rigid molecular 
systems $[18,25,26]$. The set-valued maps of symmetric permutation groups that are based on the chemical identity groups of reference isomers in families of permutation isomers belong to the most powerful qualitative mathematical devices in stereochemistry $\left.{ }^{26}\right]$.

The chiral genus, a quantitative measure of chemical chirality $\left[{ }^{27}\right]$, is part of this unified theoretical treatment of stereochemistry, and enables for the first time to define asymmetric syntheses precisely enough to discriminate clearly between these and other types of stereoselective reactions of chiral molecules $\left[{ }^{27}\right]$.

In 1965 the mathematician G. Kaufhold and the present author began using computers (IBM 7074) in ch mistry in order to gain qualitative insights. The computer-assisted analysis of the concentration dependent stereoselective 4CC yielded a mathematical model of its reaction mechanism $\left[{ }^{28}\right]$. A concurrent project was the development of a computer program for the design of optimum peptide and protein syntheses, based 4CC and conventional preparative methods $\left[{ }^{29}\right]$. About that time various other research groups also began to develop non-numerical problem-solving computer programs for chemistry $\left[{ }^{30},{ }^{31}\right]$.

In 1969 the topologist J. Dugundji and the present author started a symbiotic collaboration, one, generating concepts, abstractions and translations of chemistry into mathematics and vice versa, representing objects of chemistry by objects of mathematics, and the other, solving the corresponding mathematical problems and creating the required new formalisms $\left[{ }^{32}\right]$.

The theory of the bond/electron and reaction matrices (BE- and Rmatrices), an algebraic model of the logical structure of constitutional chemistry, was formulated in $1971 / 72{ }^{[33}$. This qualitative mathematical model of constitutional chemistry serves as the basis of diverse strictly logic-oriented computer programs for the deductive solution of chemical problems [ $\left.{ }^{34}\right]$.

When chemistry is confined to a fixed collection of atoms $A=$ $=\left\{A_{1}, \ldots, A_{n}\right\}$, it has well-defined invariancies and boundary conditions, and its logical structure is clearly recognizable. An ensemble of molecules (EM) that contains each atom of A exactly once is called an EM of A, $\operatorname{EM}(\mathrm{A})$. The family of all isomeric $\operatorname{EM}(\mathrm{A})$ is denoted by $\operatorname{FIEM}(\mathrm{A})$. A theory of FIEM(A) is a theory of chemistry as a whole, because any collection of atoms can serve as A.

Within a FIEM $(A)$, all chemical reactions are isomerizations of EM. The conversion of EM(B) $\in \operatorname{FIEM}(\mathrm{A})$ at the beginning of a reaction into $\mathrm{EM}(\mathrm{E}) \in \mathrm{FIEM}(\mathrm{A})$ at the end of a reaction is represented by the matrix equation

$$
\mathrm{B}+\mathrm{R}=\mathrm{E} .
$$

Here the $n \times n$ symmetric BE-matrices $\mathrm{B}=\left\langle b_{i j}\right\rangle$ and $\mathrm{E}=\left\langle e_{i j}\right\rangle$ with integer entries describe the chemical constitution of $E M(B)$ and $E M(E)$, and the $\mathrm{R}$-matrix $\mathrm{R}$ represents a scheme of valence electron redistribution during the reaction $\mathrm{EM}(\mathrm{B}) \rightarrow \mathrm{EM}(\mathrm{E})$. Since $n \times n$ with their $n^{2}$ entries are geometrically representable as points, or vectors, in $n^{2}$-dimensional Euclidean space an FIEM may be visualized as a lattice of points in an $n^{2}$. space, and their interconversions by chemical reactions as vectors that connect the points.

In terms of $\mathrm{L}_{1}$-metric («taxi driver distance»), the distance between the points $P(B)$ and $P(E)$ that represent $E M(B)$ and $E M(E)$ is

$$
d(\mathrm{~B}, \mathrm{E})=\sum_{i j}\left|b_{i j}-e_{i j}\right|
$$

It is called the chemical distance, because it has an immediate chemical 
meaning; it corresponds to the minimum number of valence electrons that must be redistributed in order to interconvert EM(B) and EM(E).

The principle of minimum chemical distance (PMCD) $\left[{ }^{26}\right]$ says that a chemical reaction proceeds preferably with the redistribution of a minimum number of valence electrons. This is a modern, quantitative, computeroriented version of the classical principle of minimum structure change. The PMCD follows from the theory of the BE- and R-matrices [32, 33$]$.

The equation $B+R=E$ has two types of solutions. When a BE-matrix $B$ is given, the pairs (R, E) are the solutions (type $I)$, and when $R$ is given, the pairs (B, E) are the solutions (type II). The reaction generators of type I (RG I) and type II (RG II) accomplish this and are the «engines» of the mathematically based computer program for the deductive solution of chemical problems [34, $\left.{ }^{35}\right]$.

The program RAIN $\left.{ }^{36}\right]$ (Reaction And Intermediates Network) contains an RG I. RAIN manufactures in a bilateral mode networks of reaction pathways, or mechanistic pathways. It has proven its power and usefulness in the elucidation of reaction mechanisms $\left[{ }^{37}\right]$. RAIN will also be a functional unit in a system for bilateral synthesis design $\left[{ }^{35}\right]$.

The program IGOR $\left.{ }^{38}\right]$ (Interactive Generation of Organic Reactions) follows a hierarchical classification of chemical reactions, interactively guided by the user. IGOR has already «invented» structures $\left[{ }^{20}\right]$, and some new reactions $[38,39]$, e. g. $17+18 \rightarrow 19$.

F6

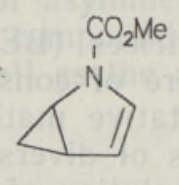

17

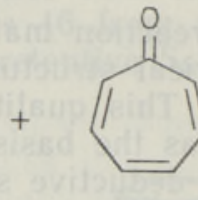

18

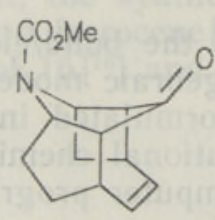

19

IGOR 2, a user-friendly PC version of IGOR, is available as a public domain program $\left[{ }^{40}\right]$, RAIN will follow soon.

The new level of abstraction that has been reached in chemistry through global qualitative mathematical models of the logical structure of chemistry will hopefully enter the minds of chemists, as a grammar of chemistry, being used not only when problems are solved with computer assistance, but hopefully also when chemists think, or when they teach chemistry.

\section{REFERENCES}

1. Ugi, I. // A. R. Katritsky, C. Rees, K. T. Potts (eds). Comprehensive Heterocyclic Chemistry. New York, 1984, 5, 839.

2. Ugi, I. (ed.). Isonitrile Chemistry. New York, 1971.

3. Hagedorn, J., Tönjes, H. // Pharmazia, 1956, 11, 409; 1957, 12, 567.

4. Hertler, W. R., Corey, E. J. // J. Org. Chem., 1958, 23, 1221.

5. Ugi, I., Meyr, R. // Angew. Chem., 1958, 70, 702.

6. Ugi, I., Betz, W., Fetzer, U., Offermann, K. // Chem. Ber., 1961, 94, 2814.

7. Ugi, I., Offermann, K., Herlinger, H. // Angew. Chem., 1964, 76, 613; Angew. Chem. Int. Ed. Engl., 1964, 3, 656.

8. Obrecht, R., Herrmann, R., Ugi, I. // Synthesis, 1985, 400.

9. Ugi, I., Meyr, R., Fetzer, U., Steinbrückner, C. // Angew. Chem., 1959, 71, 386; Ugi, I. // Angew. Chem., 1962, 74, 9; Angew. Chem. Int. Ed. Engl., 1962, 1, 8.

10. McFarland, J. W. // J. Org. Chem., 1963, 28, 2179; Sjöberg, K. // Sven. Kem. Tidskr., $1963,75,493$.

11. Bauer, J., Fontain, E., Ugi, I. // Anal. Chim. Acta, 1988, 210, 123.

12. Ugi, I., Lohberger, E., Karl, R. // B. M. Trost, C. H. Heathcock (eds). Comprehensive Organic Synthesis: Selectivity for Synthetic Efficiency, 2. London (in print). 
13. Westinger, B., Ugi, I. // W. König (ed.). Chemistry of Peptides and Proteins, 4. Proc. German-Soviet Peptide Symposium, 1987. Tübingen (in print).

14. Ugi, I. et al // Y. Wolman (ed.). Peptides 1974. Jerusalem, 1975, 71.

15. Herrmann, R., Ugi, I. // Tetrahedron, 1981, 37, 1001.

16. Gokel, G. W., Marquarding, D., Ugi, I. // J. Org. Chem., 1972, 37, 3052.

17. Marquarding, D., Klusacek, H., Gokel, G., Hoffmann, P., Ugi, I. /l J. Amer. Chem. Soc., 1970, 92, 5389 .

18. Ugi, I. // Chimia, 1986, 40, 340.

19. Eckert, H. et. al. // Pure \& Appl. Chem., 1979, 51, 1219.

20. Ugi, I. et. al. // Chemica Scripta, 1986, 26, 205.

21. Ugi, I. et. al. // Angew. Chem., 1970, 82, 741; Angew. Chem. Int. Ed. Engl., 1970, 9, 703 .

22. Ugi, I. et. al. // Accounts Chem. Res., 1971, 4, 288.

23. Lemmen, $P$. et. al. // Chemica Scripta, 1988, 28, 451

24. Ugi, I. et. al. // Phosphorus \& Sulfur (submitted).

25. Ugi, I. et. al. // Perspectives in Theoretical Stereochemistry. Lecture Note Series. Heidelberg, 1984, 36.

26. Ugi, I. et. al. // M. Johnson, G. Maggiora (eds). Concepts and Applications of Chemical Similarity. New York, 1989 (in print).

27. Dugundji, J. et. al. // Topics Curr. Chem., 1978, 75, 165.

28. Ugi, I., Kaufhold, G. // Lieb. Ann. Chem., 1967, 709, 19.

29. Ugi, I. // Rec. Chem. Progr., 1969, 30, 389.

30. Lederberg, J. et. al. // J. Amer. Chem. Soc., 1969, 91, 2973.

31. Corey. E. J. et. al. // J. Amer. Chem. Soc., 1972, 94, 421, 431.

32. Ugi, I. // J. Brandt, I. Ugi (eds). Computers in Chemical Research and Education. Stuttgart, 1989, 345.

33. Dugundii, J., Ugi, I. // Top. Curr. Chem., 1973, 39, 19.

34. Bauer, J. et. al. // Anal. Chim. Acta, 1988, 210, 123; Ugi, I. et. al // Anal. Chim. Acta (submitted).

35. Ugi, I. et. al. // Wiss. Zeitung T. H. Leuna-Merseburg, 1989, 31, 9.

36. Fontain, E. et. al. // Chem. Letters, 1987, 37.

37. Fontain, E. et. al. // Z. Naturforsch., 1987, 42 B, 889.

38. Bauer, J., Ugi, I. // J. Chem. Res., 1982, (S), 298; 1982, (M), 3101, 3201; Bauer, J. et. al. // Chimia, 1985, 39, 43.

39. Forstmeyer, D. et. al. // Angew. Chem., 1988, 100, 1618; Angew. Chem. Int. Ed. Engl., $1988,27,1558$.

40. Bauer, J. // Tetrahedron Comp. Meth., (submitted).

Munich Technical University

Received June 21, 1989

\section{UGI}

\section{PENTASOOLIST MULTIDIMENSIOONILISE KEEMIANI}

On käsitletud neljakomponendilise kondensatsiooni (1959. a. tuvastatud 4CC e. Ugi reaktsiooni) mõju artiklis toodud autorite uuringutele. 4CC-reaktsiooni aluseks on pentasooli sünteesivôimaluste uurimisel avastatud isotsüaniidide sünteesimenetlus formamiidide dehüdrateerimisel. 4CC-reaktsionni kasutamine peptiidide ja $\beta$-laktaamide sünteesil viis uute kaitsegruppide tehnika ja fosforüülimiskeemia meetodite arendamisele. See tingis edasised stereokeemilised uuringud, mille tulemused said aluseks keemia loogilise struktuuri kvalitatiivsete matematiliste mudelite formuleerimisele ning nende kasutamisele mitmemõōtmelistes Eukleidese ruumides. Viimastel pōhinevadki koostatud raaliprogrammid keemiliste problcemidẹ dẹduktiivseks lahendamișeks,

\section{И. уГИ}

\section{ОТ ПЕНТАЗОЛА ДО МУЛЬТИДИМЕНСИОНАЛЬНОИ ХИМИИ}

Открытие в 1959 г. реакции четырехкомпонентной конденсации (4СС или реакции Уги) оказало влияние на направление исследований многих ученых. В основу реакции 4СС положен метод синтеза изоцианидов дегидратацией формамидов, разработанный при изучении путей синтеза пентазола. Использование реакции 4СС при синтезе пептидоз и $\beta$-лактамов привело к развитию ковой технологии создания зацитных групп, а также методов химии фосфорилирования. Реакция 4СС стала также основой для дальнейшего проведения стереохимнческих исследований, результаты которых позволили сформулировать качественные математическне модели логических структур химии и использовать их в многомерном евклидовом пространстве, а также составить компьютерные программы для дедуктивного решения химических проблем. 